\title{
INFLUENCE OF PHOTOPERIOD AND AIR TEMPERATURE ON THE GROWTH, FLOWERING AND MATURATION OF SOYBEAN (Glycine max (L.) Merrill) ${ }^{1}$
}

\author{
G.M.S. CÂMARA ${ }^{2}$; T. SEDIYAMA ${ }^{3}$; D. DOURADO-NETO ${ }^{2,3}$; M.S. BERNARDES ${ }^{2}$ \\ ${ }^{3}$ Depto. de Agricultura-ESALO/USP, C.P. 9, CEP: 13418-900 - Piracicaba, SP - Brazil \\ ${ }^{3}$ Depto. de Agricultura-UFV, C.P. 365, CEP: 36560-000 - Vicosa, MG - Brazil. \\ Bolsita do CNPq
}

\begin{abstract}
Whit the purpose to evalunte the effect of short (12 hours) and long (13 and 14 hours) photoperiods and aif temperature regimes (winter and summer growing seasons) on soybean behaviour, greenhouse experiments were installed at the Federal Univeratty of Vicosa, Brasil, from June 1984 to December 1985. In each experiment, under a completely rundomized desigm with 12 treatments (coybean cultivars) and eight replicates: duration of vegetative period from emergency to atage R1 or flowering (DVP, in days); plant helght (PH, m); number of nodes per plant at stage R1 (NNP); and duration of soybean cycle from emergency to stage R7 or physiological maturity point (DC, days), were evaluated. The results permit to conclude that: the vegetative period from emergency to fowering and the juvenile period are significantly affected by the photoperiod and temperature differences; shorter photoperiods or higher temperatures anticipate flowering; longer photoperiods under the same temperature regime or higher temperature under the same photoperiod regime result in higher plants.
\end{abstract}

Key words: phenology, plant height, photoperiodism

\section{INFLUENCIA DO FOTOPERTODO E DA TEMPERATURA DO AR NO CRESCIMENTO, FLORAÇÃo E MATURAÇÃO DA SOJA (Glycine max (L) Merrill)}

RESUMO: Experimentos em casa-de-vegetaciso visando eatudar o comportamento de cultivares de soja perante fotoperiodo curto (12 horas) e longo (13 e 14 horas) e na presença de temperaturas varifiveis em functo de diferentes épocas de semeadura, form instalados na Universidade Federal de Viçose, MG, Brasil, durante o perfodo de junho de 1984 a dezembro de 1985. Delineado inteiramente so acaso, cada experimento contou com doze cultivares de soja repetidos olto vezes por Epoca. Avaliaram-se as seguintes caracterfiticas: duraçĭo do subperíodo emergência - Início do florescimento, altura de planta e número de nós vegetativos formados por planta e duraça do subperiodo emergência - maturidade fislologica. Concludu-se que a fase fenológica da soja compreendida entre a emergência e o infelo do foreacimento 6 significativamente infuenciada pelas variacós do fotoperfodo e da temperatura do ar; fotoperfodo e temperatura interferem com duracia fenológica do perfodo juvenil da soja e acréscimos de fotoperiodo e de temperatura antecipam o forescimento da soja e aunentam a altura de suas plantas.

Descritores: fenologia, alturn de planta, fotoperlodismo

\section{INTRODUCTION}

The photoperiod is defined as the time, within 24 hours of the terrestrial day, when there is light or sun bright (Ometto, 1981) also called daylength and defined as the time in hours between sunrise and sunset (Goudriaan \& van Laar, 1994). Daylength, temperature and rainfall are the most important climatic factors to select a region for soybean cultivation and production (Câmara, 1991).
Latitude determines the daylength pattern. In soybean, a short-day plant, daylength affects the development rate from emergence to flower induction and particularly determines the time necessary for flowering (Marcos Filho et al., s/d; Câmara, 1992). In what concerns the air temperature, it is well known that higher temperatures during the growing season favor faster development rates of this crop and reduce time for flowering (Major et al., 1975a; Major et al., 1975b; Miyasaka \& Medina, 1970).

Presented at 4th Congress of the European Society for Agronomy, 7-11 July, 1996. Veldhoven-Wageningen. The Netherlands 
Literature about the correlation between photoperiodic and temperature effects on soybean development is scarce. The objective of the present study was to evaluate the effects of these two climatic factors on growth and time for flowering and grain maturation of some soybean cultivars.

\section{MATERIAL AND METHODS}

Greenhouse experiments were installed at Federal University of Viçosa, state of Minas Gerais, Brazil (Latitude: $20^{\circ} 45^{\prime}$ South. Longitude: $42^{\circ} 51^{\prime}$ West. Altitude: $650 \mathrm{~m}$ ). The experiments were conducted using twelve Brazilian cultivated varieties: Cristalina, Doko, IAC-6, IAC-7, IAC-8, Paraná, Primavera, Savana, Tropical, UFV-1, UFV-4, and UFV-5 (Sediyama et al., 1981). The following combinations of growing period and photoperiod were studied:

- Winter season-1984: from June 18, 1984 until December 4, 1984 with short-days (photoperiod $=12$ hours) and long-days (photoperiod $=13$ hours).

- Summer season-1984/1985: from December 14, 1984 until May 26, 1985 with short-days (photoperiod $=12$ hours) and longdays (photoperiod $=13$ hours).

- Winter season-1985: from July 17, 1985 until December 23, 1985 with short-days (photoperiod $=12$ hours) and long-days (photoperiod $=14$ hours).

The daylength of 12,13 and 14 hours were used to simulate the natural photoperiodic conditions comparable to those of the Brazilian soybean growing regions of the Equator (Latitude $=0^{\circ}$ ), and of the summer solstice in tropical latitudes of the central high-plains (Latitude $=15^{\circ}$ to $19^{\circ} \mathrm{S}$ ) and of the South States (Latitude $=30^{\circ}$ to $32^{\circ} \mathrm{S}$ ), respectively. The three photoperiods were kept constant inside of the greenhouses, during the entire growing season, by artificial lights. Sowing the crop in different seasons allowed to evaluate the effect of three different temperature regimes. Daily maximum and minimum temperature were monitored in all greenhouses during the three growing seasons.

We adopted for each photoperiod and growing season a completely randomized experimental design with 12 treatments (soybean cultivars) in eight replicates. Each replicate was represented by a pot with $3 \mathrm{~kg}$ of soil with two soybean plants. To compare the effect of different photoperiod within the same growing season or the temperature effect of different growing seasons with the same photoperiod, we adopted statistical analysis techniques for group of experiments. Significant differences were evaluated with test of Tukey at $5 \%$ probability level.

The phenological staging scale of Fehr \& Caviness (1977) reviewed by Ritchie et al. (1994) was adopted to estimate: duration of vegetative period from emergency to stage $\mathrm{R} 1$ or flowering (DVP, in days); plant height (PH, m); number of nodes per plant at stage Rl (NNP); and duration of soybean cycle from emergency to stage R7 or physiological maturity point (DC, days).

\section{RESULTS AND DISCUSSION}

Long-day conditions of 13 and 14 hours daylength extended DVP, for al cultivars in every growing season, in average $28.6 \%$ to $48.8 \%$ in comparison to short-day conditions of 12 hours daylength (TABLES 1,2 and 3). As a result of a larger vegetative period, soybean plants were higher $(42.4 \%$ to $103 \%)$ and presented a larger number of nodes $(33.8 \%$ to $57.3 \%)$. The duration of soybean cycle (DC) was also extended in average $2.3 \%$ to $4 \%$ under long-day conditions, although not as much as for the vegetative period.

Since the temperature in the same growing season was not significantly different between both daylength conditions, the extension the vegetative period under longer days was consequence of the daylength itself. Thus, the critical daylength at which flower formation is initiated varies according to photoperiodic conditions during juvenile phase or are dependent of the plant size.

The differences between the largest and lowest values of mean square error permitted to compare the results of the first and second growing season, to evaluate the temperature effect (TABLES 4 and 5). 
TABLE 1 - Duration of vegetative period from emergency to flowering (DVP, days), plant height (PH, m), number of nodes per plant (NNP), and duration of soybean cycle from emergency to physiological maturity point (DC, days) for two photoperiods (12 and 13 hours) during winter season-1984. Federal University of Viçosa, Brazil.

\begin{tabular}{|c|c|c|c|c|c|c|c|c|}
\hline \multirow{2}{*}{$\begin{array}{l}\text { Cultivated } \\
\text { Varieties }\end{array}$} & \multicolumn{4}{|c|}{12 hours } & \multicolumn{4}{|c|}{13 hours } \\
\hline & DVP & $\overline{\text { PH }}$ & NNP & $\overline{D C}$ & DVP & PH & NNP & $\overline{D C}$ \\
\hline Cristalina & 72.1 & 0.754 & 9.1 & 152.9 & 92.7 & 1.003 & 12.6 & 157.6 \\
\hline Doko & 81.9 & 0.687 & 9.4 & 152.2 & 100.1 & 1.025 & 13.0 & 157.2 \\
\hline IAC-6 & 72.9 & 0.651 & 7.6 & 143.9 & 91.8 & 1.013 & 10.8 & 148.6 \\
\hline IAC-7 & 81.3 & 0.644 & 9.8 & 148.6 & 94.6 & 0.872 & 12.3 & 152.6 \\
\hline IAC-8 & 79.0 & 0.681 & 8.7 & 148.8 & 85.6 & 1.084 & 11.9 & 154.6 \\
\hline Paraná & 48.1 & 0.455 & 6.4 & 127.2 & 67.6 & 0.677 & 8.0 & 128.6 \\
\hline Primavera & 48.9 & 0.486 & 6.9 & 120.7 & 65.5 & 0.711 & 8.4 & 122.9 \\
\hline Savana & 73.3 & 0.657 & 8.4 & 144.4 & 93.5 & 0.827 & 11.5 & 146.4 \\
\hline Tropical & 88.4 & 0.926 & 10.6 & 158.5 & 101.9 & 1.028 & 12.1 & 160.1 \\
\hline UFV-1 & 45.1 & 0.551 & 6.6 & 132.8 & 70.2 & 0.761 & 8.8 & 134.1 \\
\hline UFV-4 & 44.4 & 0.425 & 5.1 & 134.7 & 65.8 & 0.773 & 8.1 & 137.6 \\
\hline UFV-S & 48.9 & 0.517 & 7.0 & 138.6 & 79.6 & 0.827 & 10.7 & 142.4 \\
\hline Mean & 65.4 & 0.620 & 8.0 & 141.9 & 84.1 & 0.883 & 10.7 & 145.2 \\
\hline C.V. & 1.3 & 16.600 & 9.9 & 0.5 & 0.9 & 14.500 & 9.7 & 0.4 \\
\hline M.S.D. $^{2}$ & 1.4 & 0.172 & 1.3 & 1.3 & 1.2 & 0.215 & 1.7 & 1.0 \\
\hline
\end{tabular}

'Coefficient of variation (\%)

${ }^{2}$ Minimum significant difference (Tukey test. Significance level 5\%).

TABLE 2 - Duration of vegetative period from emergency to flowering (DVP, days), plant height (PH, $\mathrm{m}$ ), number of nodes per plant (NNP), and duration of soybean cycle from emergency to physiological maturity point (DC, days) for two photoperiods (12 and 13 hours) during summer season-1984/1985. Federal University of Viçosa, Brazil.

\begin{tabular}{|c|c|c|c|c|c|c|c|c|}
\hline \multirow{2}{*}{$\begin{array}{l}\text { Cultivated } \\
\text { Varieties }\end{array}$} & \multicolumn{4}{|c|}{12 hours } & \multicolumn{4}{|c|}{13 hours } \\
\hline & DVP & PH & NNP & DC & DVP & PH & NNP & DC \\
\hline Cristalina & 43.3 & 0.808 & 7.4 & 147.3 & 65.3 & 1.433 & 12.2 & 148.6 \\
\hline Doko & 50.6 & 0.778 & 8.9 & 138.4 & 70.3 & 1.581 & 13.1 & 142.6 \\
\hline $1 A C-6$ & 46.1 & 0.829 & 7.3 & 133.1 & 65.7 & 1.671 & 12.1 & 135.7 \\
\hline IAC-7 & 44.1 & 0.807 & 8.0 & 138.4 & 62.6 & 1.396 & 11.9 & 139.2 \\
\hline IAC-8 & 47.4 & 0.877 & 7.5 & 141.3 & 64.4 & 1.696 & 11.4 & 144.2 \\
\hline Paraná & 34.1 & 0.577 & 6.1 & 122.3 & 56.7 & 1.322 & 10.0 & 124.9 \\
\hline Primavera & 36.5 & 0.618 & 7.2 & 117.9 & 58.4 & 1.475 & 11.4 & 125.6 \\
\hline Savana & 43.1 & 0.708 & 7.4 & 140.4 & 63.1 & 1.246 & 11.6 & 142.9 \\
\hline Tropical & 57.7 & 1.131 & 9.9 & 149.6 & 74.9 & 1.863 & 13.3 & 153.8 \\
\hline UFV-1 & 34.3 & 0.621 & 7.1 & 128.6 & 60.7 & 1.668 & 11.9 & 134.6 \\
\hline UFV-4 & 36.5 & 0.603 & 6.4 & 130.1 & 60.3 & 1.556 & 11.5 & 134.3 \\
\hline UFV.5 & 40.3 & 0.612 & 7.1 & 136.0 & 62.3 & 1.299 & 11.6 & 138.8 \\
\hline Mean & 42.8 & 0.747 & 7.5 & 135.3 & 63.7 & 1.517 & 11.8 & 138.8 \\
\hline c.V. & 1.7 & 23.400 & 11.0 & 0.5 & 1.1 & 24.400 & 11.7 & 0.6 \\
\hline M.S.D. ${ }^{2}$ & 1.2 & 0.294 & 1.4 & 1.1 & 1.2 & 0.621 & 2.3 & 1.3 \\
\hline
\end{tabular}

${ }^{1}$ Coefficient of variation (\%)

${ }^{2}$ Minimum significant difference (Tukey test. Significance level 5\%). 
TABLE 3 - Duration of vegetative period from emergency to flowering (DVP, days), plant height (PH, $\mathrm{m}$ ), number of nodes per plant (NNP), and duration of soybean cycle from emergency to physiological maturity point (DC, days) for two photoperiods (12 and 14 hours) during winter season-1985. Federal University of Viçosa, Brazil.

\begin{tabular}{|c|c|c|c|c|c|c|c|c|}
\hline \multirow{2}{*}{$\begin{array}{l}\text { Cultivated } \\
\text { Varieties }\end{array}$} & \multicolumn{4}{|c|}{12 hours } & \multicolumn{4}{|c|}{14 hours } \\
\hline & DVP & $\overline{\text { PH }}$ & NNP & $\overline{D C}$ & DVP & $\overline{\text { PH }}$ & NNP & $\overline{D C}$ \\
\hline Cristalina & 74.9 & 0.776 & 9.3 & 142.5 & 96.6 & 1.103 & 11.5 & 148.5 \\
\hline Doko & 83.2 & 0.698 & 9.5 & 143.5 & 102.4 & 1.144 & 12.2 & 148.8 \\
\hline IAC-6 & 77.8 & 0.791 & 7.9 & 137.4 & 97.4 & 1.326 & 12.4 & 143.9 \\
\hline IAC-7 & 83.9 & 0.775 & 9.5 & 139.3 & 99.6 & 1.148 & 11.8 & 146.1 \\
\hline IAC-8 & 81.1 & 0.746 & 8.8 & 139.8 & 94.5 & 1.292 & 11.4 & 147.2 \\
\hline Paraná & 54.6 & 0.526 & 6.6 & 127.6 & 78.9 & 0.848 & 9.4 & 132.7 \\
\hline Primavera & 55.4 & 0.536 & 7.1 & 119.5 & 78.6 & 0.859 & 9.9 & 125.6 \\
\hline Savana & 79.2 & 0.665 & 9.8 & 141.2 & 99.1 & 0.920 & 11.4 & 144.4 \\
\hline Tropical & 89.9 & 0.978 & 10.5 & 147.2 & 103.6 & 1.259 & 12.6 & 149.8 \\
\hline UFV-1 & 53.8 & 0.563 & 7.2 & 129.3 & 79.7 & 0.858 & 9.8 & 135.3 \\
\hline UFV-4 & 51.1 & 0.498 & 5.6 & 130.6 & 80.0 & 0.933 & 10.1 & 135.8 \\
\hline UFV-5 & 55.3 & 0.528 & 7.3 & 132.2 & 92.7 & 0.923 & 10.6 & 138.5 \\
\hline Mean & 70.0 & 0.673 & 8.2 & 135.8 & 91.9 & 1.051 & 11.1 & 141.4 \\
\hline c.V. & 1.0 & 5.600 & 5.4 & 0.3 & 0.5 & 5.200 & 3.6 & 0.3 \\
\hline M.S.D. ${ }^{2}$ & 1.1 & 0.063 & 0.7 & 0.7 & 0.8 & 0.092 & 0.7 & 0.7 \\
\hline
\end{tabular}

${ }^{1}$ Coefficient of variation (\%)

${ }^{2}$ Minimum significant difference (Tukey test. Significance level 5\%).

TABLE 4 - Duration of soybean vegetative period from emergency to flowering (DVP, days) and plant height (PH, m) for two growing seasons (GS1 = Winter season 1984 and GS2 = Summer season 1984/1985) and respectively differences between growing seasons (GS1-GS2) at short photoperiod (12 hours). Federal University of Viçosa, Brazil.

\begin{tabular}{|c|c|c|c|c|c|c|}
\hline \multirow{2}{*}{$\begin{array}{l}\text { Cultivated } \\
\text { Varieties }\end{array}$} & \multicolumn{3}{|c|}{ DVP } & \multicolumn{3}{|c|}{ PH } \\
\hline & GS1 & GS2 & GS1-GS2 & GS1 & GS2 & GS1-GS2 \\
\hline Cristalina & 72.1 & 43.3 & 28.8 & 0.754 & 0.808 & -0.054 \\
\hline Doko & 81.9 & 50.6 & 31.3 & 0.687 & 0.778 & -0.091 \\
\hline IAC-6 & 72.9 & 46.1 & 26.8 & 0.651 & 0.829 & -0.178 \\
\hline IAC-7 & 81.3 & 44.1 & 37.2 & 0.644 & 0.807 & -0.163 \\
\hline IAC-8 & 79.0 & 47.4 & 31.6 & 0.681 & 0.877 & -0.196 \\
\hline Paraná & 48.1 & 34.1 & 14.0 & 0.455 & 0.577 & -0.122 \\
\hline Primavera & 48.9 & 36.5 & 12.4 & 0.486 & 0.618 & -0.132 \\
\hline Savana & 73.3 & 43.1 & 30.2 & 0.657 & 0.708 & -0.051 \\
\hline Tropical & 88.4 & 57.7 & 30.7 & 0.926 & 1.131 & -0.205 \\
\hline UFV-1 & 45.1 & 34.3 & 10.8 & 0.551 & 0.621 & -0.070 \\
\hline UFV-4 & 44.4 & 36.5 & 7.9 & 0.425 & 0.603 & -0.178 \\
\hline UFV.5 & 48.9 & 40.3 & 8.6 & 0.517 & 0.612 & -0.095 \\
\hline Mean & 65.4 & $\overline{42.8}$ & 22.6 & 0.620 & 0.747 & -0.127 \\
\hline C.V. ${ }^{\top}$ & 1.3 & 1.7 & - & 16.600 & 23.400 & $\cdot$ \\
\hline M.S.D. ${ }^{2}$ & 1.4 & 1.2 & - & 0.172 & 0.294 & - \\
\hline
\end{tabular}

${ }^{1}$ Coefficient of variation $(\%)$

${ }^{2}$ Minimum significant difference (Tukey test. Significance level 5\%). 
TABLE 5 - Duration of soybean vegetative period from emergency to flowering (DVP, days) and plant height $(\mathrm{PH}, \mathrm{m})$ for two growing seasons (GS1 = Winter season 1984 and GS2 = Summer season 1984/1985) and respectively differences between growing seasons (GS1-GS2) at long photoperiod (13 hours). Federal University of Viçosa, Brazil.

\begin{tabular}{|c|c|c|c|c|c|c|}
\hline \multirow{2}{*}{$\begin{array}{l}\text { Cultivated } \\
\text { Varieties }\end{array}$} & \multicolumn{3}{|c|}{ DVP } & \multicolumn{3}{|c|}{ PH } \\
\hline & GS1 & GS2 & GS1-GS2 & GS1 & GS2 & GS1-GS2 \\
\hline Cristalina & 92.7 & 65.3 & 27.4 & 1.003 & 1.433 & -0.430 \\
\hline Doko & 100.1 & 70.3 & 29.8 & 1.025 & 1.581 & -0.556 \\
\hline IAC-6 & 91.8 & 65.7 & 26.1 & 1.013 & 1.671 & -0.658 \\
\hline IAC-7 & 94.6 & 62.6 & 32.0 & 0.872 & 1.396 & -0.524 \\
\hline IAC-8 & 85.6 & 64.4 & 21.2 & 1.084 & 1.696 & -0.612 \\
\hline Paranh & 67.6 & 56.7 & 10.9 & 0.677 & 1.322 & -0.645 \\
\hline Primavera & 65.5 & 58.4 & 7.1 & 0.711 & 1.475 & .0 .764 \\
\hline Savana & 93.5 & 63.1 & 30.4 & 0.827 & 1.246 & .0 .419 \\
\hline Tropical & 101.9 & 74.9 & 27.0 & 1.028 & 1.863 & -0.835 \\
\hline UFV-1 & 70.2 & 60.7 & 9.5 & 0.761 & 1.668 & -0.907 \\
\hline UFV-4 & 65.8 & 60.3 & 5.5 & 0.773 & 1.556 & -0.783 \\
\hline UFV-S & 79.6 & 62.3 & 17.3 & 0.827 & 1.299 & -0.472 \\
\hline Mean & 84.1 & 63.7 & 20.4 & 0.883 & 1.517 & .0 .634 \\
\hline c.V. ${ }^{\prime}$ & 0.9 & 1.1 & - & 14.500 & 24.400 & $\cdot$ \\
\hline M.S.D. ${ }^{2}$ & 1.2 & 1.2 & 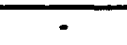 & 0.215 & 0.621 & - \\
\hline
\end{tabular}

${ }^{1}$ Coefficient of variation (\%)

${ }^{2}$ Minimum significant difference (Tukey test. Significance level 5\%)

The duration of vegetative period was reduced from the winter to the summer growing seasons, independently of photoperiodic conditions. The enhancement of development rate reducing the juvenile period and anticipating flowering under summer growing season was probably result of the warmer temperatures. Despite the shorter juvenile and vegetative periods of summer growing season compared to winter growing seasons, higher temperatures favored growth of soybean resulting in higher plants in summer.

Under 12 hours daylength conditions during the first (Winter season 1984) and second (Summer 1984/1985) growing season, the average for the maximum, minimum and daily average temperature were $31.8^{\circ} \mathrm{C}, 15.0^{\circ} \mathrm{C}$ and $23.4^{\circ} \mathrm{C}$, and $33.1^{\circ} \mathrm{C}, 22.1^{\circ} \mathrm{C}$ e $27.6^{\circ} \mathrm{C}$. respectively. The differences between growing seasons for vegetative period and daily average temperature were 22.6 days and $4.2^{\circ} \mathrm{C}$. The ration of both values indicates that a increase in $1.0^{\circ} \mathrm{C}$ resulted in 5.4 days anticipation for flowering under shortday conditions.

Under 13 hours daylength conditions during the first (Winter season 1984) and second (Summer 1984/1985) growing season, the average for the maximum, minimum and daily average temperature were $31.0^{\circ} \mathrm{C}, 15.2^{\circ} \mathrm{C}$ and $23.1^{\circ} \mathrm{C}$, and $34.0^{\circ} \mathrm{C}, 22.3^{\circ} \mathrm{C}$ e $28.2^{\circ} \mathrm{C}$. respectively. The differences between growing seasons for vegetative period and daily average temperature were 20.4 days and $5.1^{\circ} \mathrm{C}$. The ration of both values indicates that $\mathrm{a}$ increase in $1.0^{\circ} \mathrm{C}$ resulted in 4 days anticipation for flowe-ring under shortday conditions (12 hours).

\section{CONCLUSIONS}

- The vegetative period from emergency to flowering and the juvenile period are significantly affected by the photoperiod and temperature differences. Shorter photoperiods or higher temperatures anticipate flowering. 
- Longer photoperiods under the same temperature regime or higher temperature under the same photoperiod regime result in higher plants.

\section{REFERENCES}

CÂMARA, G.M.S. Efeito do fotoperiodo e da temperatura no crescimento, florescimento e maturaçato de cultivares de soja (Glycine max (L.) Merrill). Viçosa, 1991. 266p. Tese (Doctor Science) Universidade Federal de Viçosa.

CÂMARA, G.M.S. Ecofisiologia da cultura da soja. In: CÂMARA, G.M.S.; MARCOS FILHO, J.; OLIVEIRA, E.A.M. Simpbsio sobre culturn e produtividade da roja. Anals. Piracicaba: Fundaçăo de Estudos Agrários "Luiz de Queiroz", 1992, cap.9, p.129-42.

FEHR, W.R; CAVINESS, C.E. Stages of soyhean development. Ames, lowa State University of Science and Technology, 1977. 11p.

GOUDRIAAN, J.; van LAAR, H.H. Modelling potential crop growth processes: Textbook with exercices. Dordrecht, Kluwer Academic Press, 1994. 238p.

OMETTO, J.C. Bloclimatologia vegetal. São Paulo: Agronômica Ceres, 1981. 440p.

MAJOR, D.J.; JOHNSON, D.R; LUEDDERS, V.D. Evaluation of eleven thermal unit methods for predicting soybean development. Crop Science, v.15, p.172-174, 1975a.
MAJOR, D.J.; JOHNSON, D.R; TANNER, J.W.; ANDERSON, 1.C. Effects of daylength and temperature on soybean development. Crop Sclence, v. S, p.174-179, 1975b.

MARCOS FILHO, J.; GODOY, O.P.; CÂMARA, G.M.S. Tecnologia da produção. In: CÂMARA, G.M.S.; GODOY, O.P.; MARCOS FILHO, J.; REGITANOD'ARCE, M.A.B. Soja: produço, preprocessamento transformacito agrolndustrial. Săo Paulo: Secretaria da Indústria, Comércio, Ciência e Tecnologia, s/d, cap.1, p.1-39. (Série Extensão Agroindustrial, 7).

RITCHIE, S.W.; HANWAY, J.J.; THOMPSON, H.E.; BENSON, G.O. How soybean plant develops. Ames, Iowa State University of Science and Technology: Cooperative Extension Service, 1994. 20p. (Special Report, 53).

SEDIYAMA, T.; DESTRO, D.; SEDIYAMA, C.S.; TRAGNAGO, J.L.; CARRARO, I.M.; COSTA, A.B. Caractertzafín de cultivares de soja. Viçosa: Universidade Federal de Viçosa, 1981. 81p.
Recebido para publicação em 15.04 .97 Aceito para publicação em 18.05 .97 